\title{
Harmonizing UNCITRAL Model Law: A TWAIL Analysis of Cross Border Insolvency Law
}

\author{
Dwayne Leonardo Fernandes* and Devahuti Pathak**
}

\section{1 \\ Introduction}

Globalization has had a twofold effect on the world of commerce. On one hand, it has resulted in dramatic increases in the exchange of goods, services, factors of production, and the revenues that such forms of exchange generate. ${ }^{1}$ This, advocates of neoliberalism have argued, has resulted in higher GDP, higher GDP Per Capita, and better standards of living the world over. ${ }^{2}$ Sceptics remain unconvinced by these arguments due to the lack of concern for the distributional consequences of this newly created wealth. ${ }^{3}$

However, on the other hand, this increase in the volume of exchange across borders has led to an increase in the number of practical issues concerning juridical boundaries in the regulation of transnational commercial activity. In a global context characterized by the interplay between multilateral institutions ${ }^{4}$ and sovereign nations, the former have devised global norms, authored by the Global North and premised on a normative belief in the efficacy of the market mechanism, to coordinate legislative and policy-making processes across the world. ${ }^{5}$ Through the mechanism of conditionalities that, when imposed, permit or restrict access to financial resources, these multilateral agencies can pressurize nations into adopting these global norms.

* Independent Researcher.

** Advocate, High Court of Delhi and Supreme Court of India.

1 Esteban Ortiz-Ospina \& Diana Beltekian, Trade and Globalization, Our World IN DATA (2018), https://ourworldindata.org/trade-and-globalization (last visited Oct. 20, 2019).

2 Jeffrey A. Frankel \& David H. Romer, Does Trade Cause Growth?, 89 American Economic REVIEW 379, 379-99 (1999).

3 Federico Cingano, Trends in Income Inequality and Its Impact on Economic Growth (OECD Soc., Emp't \& Migration Working Paper, Paper No. 163, 2014), https://doi.org/10.1787/1815199X.

4 Dean Coldicott, The World Trade Organization, Legitimacy and the Development Problematic, WORLD BANK (2008), http://siteresources.worldbank.org/INTRAD/Resources/ DColdicott.pdf.

5 Antony Anghie, University and the Concept of Governance in International Law, in LEG ITImate Governance in Africa: International and Domestic Legal Perspectives 20, 21-40 (Edward K. Quashigah \& Obiora C. Okafor eds., 1999). 
This imposes exogenously determined constraints on States, particularly in the Third World, and limits their ability to constitute their own institutional contexts and developmental path. Thus, one adverse product of the increased globalization of commerce and the multilateral institutions' push to impose its neoliberal agenda on the Global South is the intertwined problem of local governance and economic development in the Third World. One domain in which these issues find clear articulation is the case of cross-border insolvency law. In order to examine this case meaningfully, we situate our study in the context of the current debate surrounding India's attempts to reform their insolvency law through the introduction of the Insolvency and Bankruptcy Code, 2016 (hereafter, "the Code").

The attempts to reform this legislation is of particular interest due to the fact that the prevailing idea, emanating from and emphasized by the multilateral institutions, is the adoption of the United Nations Commission on International Trade Law (hereafter, the "UnCITRAL") Model Law on Cross Border Insolvency, 1997 (hereafter, "the Model Law"). ${ }^{6}$ The logical foundations of this idea rest on the universalist notion that differences between domestic legal systems and their associated modes of governance inhibit the costless movement of capital from one economy to another, and, as such, must be made more legible through the removal of such differences. Differences in modes of governance, in the neoliberal discourse of global governance, provide a disincentive to investors. This is due to the fact that they impose additional transaction costs, ${ }^{7}$ the costs of using the domestic systems, on investors. And such increases in costs have an adverse effect on their willingness to invest.

The aim of our study is to examine the trajectories and implications of India's State Practices that began with the Eradi Committee Report, 2000, coursing through the judgement of Macquarie Bank Limited v. Shilpi Cable Technologies Limited, now culminated in the form of a draft chapter on cross border insolvency that adopts the Model Law based on the recommendations of the Report of the Insolvency Law Committee, 2018 (hereafter, "the Committee") which was constituted by the Ministry of Corporate Affairs, Government of India, and, most recently, the Cross Border Insolvency Protocol (hereafter, the "СвІP")

6 U.N. Comm'n on Int'l Trade Law, UNCITRAL Model Law on Cross-Border Insolvency 1997, https://uncitral.un.org/en/texts/insolvency/modellaw/cross-border_insolvency (adopted May 30, 1997).

7 Transaction Costs, Encyclopedia of LAW \& Economics (Boudewijn Bouckaert \& Gerrit De Geest eds., 1998), https://reference.findlaw.com/lawandeconomics/literature-reviews/ o740-transaction-costs.html (last visited Oct. 20, 2019). 
that has emerged between the parties involved in the Jet Airways case. ${ }^{8} \mathrm{~A}$ key element to understanding India's motivations in choosing to adopt the Model Law finds articulation in the rationale the Committee employed in arriving at its conclusions. Crucially, the Report also renders visible the gaps in their considerations and spaces where they have deferred to the wisdom of the Central Government in the exercise of its legislative functions.

By drawing on the Third World Approaches to International Law (hereafter, "TWAIL") as our interpretative lens, we seek to push back against the dominant thrust of the literature on cross border insolvency. The concern of this branch of scholarly activity has largely been about developing increasingly refined justifications for the adoption of the Model Law. ${ }^{9}$ A glaring gap in the literature that emerges as a consequence of this pursuit is an examination, from the bottom up, of the domestic policy considerations that go into the process of adopting the Model Law.

By situating our study in the context of the political processes of the Indian State that are concerned with enabling the adoption of the Model Law, we provide a tangible ground on which to enter into the theoretical debate - universalism versus territorialism - that characterizes the diversity of experiences in the adoption of the Model Law. Harmonization, posited as a forward march towards the inevitable unification of cross border insolvency law, is challenged through a comparative analysis of the State Practices of countries from the Global North around their experience of adopting the Model Law.

The remainder of this article is divided into three additional sections. Section two lays out the entwined logic of cross border insolvency and harmonization by examining the rationale underlying the UNCITRAL's efforts to promote the adoption of the Model Law, introduces the concept of State Practices, and examines the State Practices that have gone into India's eventual decision to adopt the Model Law. Section three compares India's experiences with the experiences of common law countries from the Global North. Section four stands in lieu of a conclusion and offers a sense in which TWAIL allows interpretation of sections two and three.

8 Jet Airways (India) Ltd. v. State Bank of India, (2019) C.P. (IB)-1968/(MB)/2019 (India).

9 An article by Mohan is a representative example. S. Chandra Mohan, Cross-border Insolvency Problems: Is the UNCITRAL Model Law the Answer?, 21 InTE RnATIONAL InSOLVENCY REVIEW 199, 211 (2012). 

Practices

In the wake of the Second World War, nations of the Third World began to cast aside their colonial yoke and won the right to self-government. At the international stage, this resulted in a chorus of articulation of Third World sovereignty that looked for, and eventually, found succour in the internationalism of the United Nations. The United Nations did not remain unmoved to these global changes and responded to them by amending its organizational form. One response, in the domain of international trade and investment, was the development of the UNCITRAL. The UNCITRAL was established as a subsidiary body of the United Nations General Assembly and was tasked with the facilitation of international trade and investment. It is important to note that the official mandate of the UNCITRAL is "to promote the progressive harmonization and unification of international trade law." ${ }^{10}$ It pursues this goal by organizing itself into Intergovernmental Working Groups that examine various facets of international trade law that develop "conventions, model laws, and other instruments that address key areas of commerce, from dispute resolution to the procurement and sale of goods."11

It is important for us to distinguish between the two goals of the UNCITRAL harmonization and unification. The former is considered a short-term goal characterized by greater coordination between States. The latter is a longerterm goal characterized by the removal of substantive differences, the source of variations in cost, in the legal modes of governance. The logic of harmonization, in essence, rests on a foundation of cost efficiency, that is, cost minimization. ${ }^{12}$ It espouses a belief that greater international trade can be produced by reducing the disincentives to international trade, namely, high transaction costs. Harmonization, in general, is seen as having "mythical qualities"13 that is synonymous with harmony. As a result, the absence of harmonization is seen

10 Provisional Agenda of the Sixty-Second Session, U.N. Doc. A/62/100, at 146 (2007).

11 Frequently Asked Questions - Mandate and History, UNCITRAL, https://uncitral.un.org/ en/about/faq/mandate_composition/history (last visited June 9, 2019).

12 Arthur Rosett, Unification, Harmonization, Restatement, Codification, and Reform in International Commercial Law, 40 American Journal of Comparative LAW 683 (1992).

13 Martin Boodman, The Myth of Harmonization of Laws, 39 THE AMERICAN JournAL OF Comparative LAW 699 (1991). 
as disharmony, an undesirable quality whose undesirableness is seen as selfevident. Thus, harmonization is a panacea to the ills of negative externalities and high transaction costs. ${ }^{14}$

In order to coherently understand the implications of the UNCITRAL's commitments to the principles of coordination and the forms that State Practices take in the domain of international trade law, namely, harmonization and unification, we will examine the idea of State Practices in the context of a Third World nation - India. We will do so in relation to India's decision to accept provisions of the Model Law as the operational framework for cross border insolvencies. The objective of this exercise is simple - an examination of State Practices that gives us a sense of the local priorities, including substantive aspects of local law, that are kept aside in order to meet international obligations.

\subsection{The Concept of State Practices}

International law is comprised of generally accepted laws, treaties between nations, and Customary International Law. Within this framework, the concept of State Practices is a constituent element of customary international law. State Practices are characterized by the general practices that States engage in that can be accepted as law. This includes actions of the State, its constituent bodies - executive, judiciary, legislature - and the individuals that occupy positions within them that keep with the international obligations of the State to the global community at large. ${ }^{15}$

\subsection{The Adoption of the Model Law as State Practice}

To understand why the adoption of the Model Law is contingent on State Practices, we may observe a debate on the form in which cross border insolvency law should be harmonized by Member States:

The Commission recalled the considerations by the Working Group on Insolvency Law on whether the text should be prepared as model legislation or as a treaty or model treaty (NCN.9/422, paras. 14-16, and NCN.9/433, paras. 16-20). The prevailing view was that the text should be completed as model legislation, the form that, because of its flexibility, was best suited to induce in the shortest possible time harmonized

14 Eleanor M. Fox, Harmonization of Law and Procedures in a Globalized World: Why, What, and How?, 6o Antitrust LaW Journal 593 (1991).

15 A. Mark Weisburd, The International Court of Justice and the Concept of State Practice, $3^{1}$ University of Pennsylvania Journal of International LaW 295 (2009). 
modernization of national laws in the area of cross-border insolvency, an area of law that hitherto had not been subject to unification. ${ }^{16}$

Owing to the fact that the Commission, as quoted above, decided to structure the Model Law as a Model Treaty, the burden of keeping in line with these obligations rested on how States chose to incorporate them into their local laws. In the context of India, this can be seen by examining three key pieces- the Eradi Committee Report, 200o, the judgement of Macquarie Bank Limited v. Shilpi Cable Technologies Limited, and the draft chapter on cross border insolvency that adopted the Model Law ${ }^{17}$ based on the recommendations of the Report of the Insolvency Law Committee, 2018 (hereafter, "the Committee") which was constituted by the Ministry of Corporate Affairs, Government of India.

\subsection{India's State Practice}

\subsubsection{Eradi Committee Report, 2000}

The Central Government constituted a High-Level Committee on Law Relating to Insolvency of Companies to examine and suggest reforms in the existing laws associated with winding up proceedings of companies and in the various stages of insolvency proceedings of companies to make them more efficient in tune with international best practices. This Committee recommended that part viI of the Companies Act, 1956 should be suitably amended to incorporate provisions of the Model Law in regard to issues on cross border insolvency.

\subsubsection{Macquarie Bank Limited v. Shilpi Cable Technologies Ltd., AIR 2018 SC 498}

In this judgment, the Supreme Court of India interpreted (i) Section 9 (3)(c) of the Code which states that the operational creditor shall, along with the application for initiating insolvency proceedings, furnish a copy of the certificate from the Financial Institutions confirming that there is no payment of an unpaid operational debt by the corporate debtor; and (ii) Section 8(1) under which demand notice of an unpaid operational debt is to be issued in favour of the foreign creditor.

16 Report of the United Nations Commission on International Law on the work of its thirtieth session, II 26, 13 U.N. Doc. A/52/17 (1997), reprinted in [1999] 28 United NATions Commission on International Trade LaW: Yearbook 7, U.N. Doc. A/CN.9/ SER.A/1997.

17 Ministry of Corp. Affairs, Report of Insolvency law Committee on Cross Border InSOLVEnCY 5 (Oct., 2018) (India), http://www.mca.gov.in/Ministry/pdf/Cross BorderInsolvencyReport_22102018.pdf. 
The Supreme Court held that the certificate to be issued under Section 9(3)(c) of the Code is a procedural provision, which is directory in nature, and also held that a fair construction of Section 9(3)(c), in the spirit sought to be achieved by the Code, leads to a conclusion that certification by a Financial Institution cannot be construed as a threshold bar or a condition precedent to initiating insolvency proceedings. The Supreme Court further read Section 30 of the Advocates Act with Sections 8 and 9 of the Code, together with the Adjudicatory Authority Rules and Forms, and concluded that a notice sent on behalf of an operational creditor by a lawyer would be valid, proper, and "in order." Thereby the Supreme Court enabled greater access to foreign operational creditors not associated with financial institutions under the Code to file applications and pursue insolvency proceedings in India.

2.3.3 Report of the Insolvency Law Committee, October $2018^{18}$

This report examined the problem of unintended exclusions under Section $29 \mathrm{~A}$ of the Insolvency and Bankruptcy Code (that disqualify certain persons from submitting resolution plans under the Code), the treatment of homebuyers as financial creditors, promotion of the resolution process through re-calibration of voting thresholds for different decisions of the committee of creditors, etc. The Committee deliberated on cross border insolvency and the insufficiency of Sections 234 and 235 of the Code, dealing with cross border insolvency in a separate chapter, though reserving exhaustive recommendations on the same. ${ }^{19}$

The Committee, in this report, noted that there was a need for a comprehensive examination of the cross border insolvency framework in India in comparison with other international jurisdictions and hence reserved the recommendations vis-à-vis a cross border insolvency to beyond the purview of this present report. ${ }^{20}$

\subsubsection{Report of Insolvency Law Committee on Cross Border Insolvency,} October 2018

Thus, pursuant to the March 2018 Report, the Insolvency Law Committee took a deep dive into the state of regulation of cross border insolvency in India and examined existing provisions in various statutes relating to cross-border insolvency, in light of adopting the Model Law. The Committee limited "application

\begin{tabular}{ll}
\hline $18 \quad I d$. at 1. \\
$19 \quad I d$. at 5. \\
$20 \quad I d$. at 13.
\end{tabular}


of cross-border insolvency provisions to corporate debtors" and considered further extending them to individual companies and enterprise groups. ${ }^{21}$

The October 2018 Report sets out some key "advantages" to adopting the Model Law, ${ }^{22}$ like increasing foreign investment by aligning India with global best practices in insolvency resolution and liquidation having a flexible option in light of differences among national insolvency laws, and it is viewed as a mode of resolution that protects public interest, gives priority to domestic insolvency proceedings over foreign proceedings, and enables a mechanism of co-operation among courts that would facilitate faster and effective conduct of concurrent proceedings. ${ }^{23}$

This October 2018 report has broadly inspected various provisions of the UNCITRAL Model Law and categorically commented on the extent to which such provisions may or may not be adopted, including various extents of modification in adoption. A brief examination of the same is as follows:

The Report firstly identifies the four main principles on which the Model Law is based:

1) Access: In order to enable foreign insolvency professionals and foreign creditors access domestic courts, the Committee, inter alia, recommends that the Central Government ought to devise a mechanism to enable such access in the current legal framework in India.

2) Recognition: The Committee identifies the system of recognition of foreign proceedings and relevant remedies by domestic courts as provided in the Model Law. The Committee recommends such recognition based on the determination of the debtor's Centre of Main Interests (hereafter, the "сом I"). Relief is recommended to be provided for likewise, on whether the foreign proceeding is a main or a non-main proceeding.

3) Cooperation: The Committee, recognising the still-evolving infrastructure of Adjudicating Authorities under the Insolvency and Bankruptcy Code (hereafter, "the IBC"), has restricted and subjected the cooperation between Adjudicating Authorities and foreign courts to guidelines to be notified by the Central Government in due course, while retaining the Model Law provisions on inter se cooperation among Adjudicating Authorities, foreign insolvency professionals, and foreign and domestic insolvency professionals.

$\begin{array}{ll}21 & \text { Id. at } 6 . \\ 22 & \text { Id. at } 5 . \\ 23 & \text { Id. at } 5^{-6 .}\end{array}$


4) Coordination: The Committee also makes recommendations on how to coordinate insolvency proceedings when they have been initiated domestically and/or when a foreign insolvency proceeding has already commenced. ${ }^{24}$

Through this Report, the Insolvency Committee, having assessed existing jurisprudence related to cross border insolvency as well as existing material "issued by the UNCITRAL for guidance on the Model Law," recommended adoption of the Model Law in the form of a draft cross border insolvency legislation (hereinafter, also referred to as "Draft Legislation" or "Draft Part Z"). ${ }^{25}$ Additionally, the Committee also recommended how various other amendments may be necessitated in subordinate legislations in light of this Report.

In fact, the Report suggests amendments to the IBC to streamline inclusion of the proposed chapter to it. These include, inter alia, amending Sections 234 and 235 to exclude corporate debtors, the inspection powers of the Iвві for adjudication of penalties against foreign representatives, amendment of section 375(3)(b) of the Companies Act, etc. ${ }^{26}$

\subsubsection{Cross Border Insolvency Protocol, 2019}

On the 17th of April, 2019, Jet Airways (India) Ltd. (hereafter, "Jet Airways") stopped operations after it ran out of cash needed to continue its services and was unable to persuade its lenders to finance further expenditure. ${ }^{27}$ Subsequently, its largest lender - the State Bank of India - initiated insolvency proceedings against Jet Airways under the IBC. Concurrently, the Dutch Court Administrator began insolvency proceedings against Jet Airways towards debts owed to lenders operating in Dutch jurisdiction.

The National Company Law Tribunal in India had initially declared all other foreign insolvency proceedings against Jet Airways null and void. However, the National Company Law Appellate Tribunal recognized the Dutch proceedings on the condition that no assets of Jet Airways in Netherlands be sold. ${ }^{28}$ The various lenders in Jet Airways proceedings agreed to the adoption of a

\footnotetext{
$24 \quad I d$. at 14.

25 Id.

26 Id. at $14-15$.

27 Anirban Chowdhury, Jet Airways Bankrupt, Goyals under Scanner, Scion Floats New Company, The Economic Times, Sept. 11, 2019, https://economictimes.indiatimes.com/ small-biz/startups/newsbuzz/jet-amid-clouds-naresh-goyals-son-launches-travel-tech -startup/articleshow/71058293.cms.

28 Press Trust of India, NCLAT Asks Jet Airways IRP to Cooperate with Dutch Court Administrator, The Eсопомic Times, Sept. 4, 2019, https://economictimes.indiatimes.com/ industry/transportation/airlines-/-aviation/nclat-asks-jet-airways-irp-to-cooperate-with -dutch-court-administrator/articleshow/70975541.cms?from=mdr.
} 
СвIP, ${ }^{29}$ due to the absence of well-defined cross border insolvency norms and delays in the adoption of the recommendations of the report discussed in the earlier Section, so as to ensure the efficient resolution of the proceedings.

Keeping in mind the Model Law, the CBIP acknowledges that Jet Airways, an Indian company, had interests in various jurisdictions around the world. However, the Centre of Main Interest of the Airline was in India and, as such, Indian proceedings would assume priority over all others and the Dutch Court Administrator would defer pronouncement of any judgement until its Indian counterpart did so. Further, parties to the CBIP agreed that they would uphold principles of coordination, communication, information, and data sharing in such a way as to maximize the value of assets of Jet Airways.

Section 13 of the CBIP articulates that the principle of comity will hold for all Courts involved in the proceedings and that the agreement to cooperate will, in no way, undermine the powers each of these Courts have in their respective jurisdictions. ${ }^{30}$

\section{Interpretation of the Model Law in Other Common Law Countries}

The Model Law is interpreted differently in different countries. Australia enacted the Model Law by annexing the Model Law as Schedule 1 to the CrossBorder Insolvency Act 2008 (Cth) (the Act) and applied it to both corporate and personal insolvency. The Model Law in Australia does not attempt to amend or insert itself into the domestic law relating to insolvency. The Model Law was enacted in Canada by "An Act to Amend the Bankruptcy and Insolvency Act, the Companies' Creditors Arrangement Act, the Wage Earner Protection Program Act and Chapter 47 of the Statutes of Canada 2005, which inserted the same into Part IV of the [Companies Creditors Arrangement Act, RSC 1985, c C-36] in respect of large corporate insolvency, and restructuring and by inserting it into Part XIII of the [Bankruptcy and Insolvency Act, RSC 1985, c B-3] in respect of other insolvencies."31

New Zealand enacted the Model Law with minor variations as Schedule 1 to the Insolvency (Cross-border) Act 2006 by making specific provisions in relation to the High Court of New Zealand acting in aid of overseas courts by enabling it to refer to "any document that relates to the Model Law on

\footnotetext{
29 Supra note 8 , at 2.

$30 \quad I d$. at 17.

31 Neil Hannan, Cross-Border Insolvency: The Enactment and InterpreTATION OF THE UNCITRAL MODEL LAW 16 (2017).
} 
Cross-Border Insolvency that originates from the United Nations Commission on International Trade Law, or its working group for the preparation of the Model Law on Cross-Border Insolvency."32 Likewise, the Insolvency Act 2000 in the UK authorized the introduction of the Model Law with or without modification by regulation. The Secretary of State enacted an amended form of the Model Law in the Cross-Border Insolvency Regulations 2006. ${ }^{33}$

Chapter 15 of the United States Bankruptcy Code was introduced in October 2005 by the Bankruptcy Abuse Prevention and Consumer Protection Act of 2005, to govern transnational bankruptcies and is applicable to insolvency of a debtor that conducts its business in more than one country, based on the UNCITRAL Model Law. Section 1501(a) of the United States Bankruptcy Code enumerates the five objectives of Chapter 15: (1) cooperation between United States courts and foreign courts; (2) "greater legal certainty for trade and investment"; (3) "fair and efficient administration of cross-border insolvencies that protects the interests of all creditors, and other interested entities, including the debtor"; (4) "protection and maximization of the value of the debtor's assets"; and (5) "facilitation of the rescue of financially troubled businesses, thereby protecting investment and preserving employment." Chapter 15, moreover, requires American courts to "cooperate to the maximum extent possible with a foreign court or a foreign representative." Chapter 15 further defines a foreign main proceeding as one pending in the country where the debtor has their Centre of Main Interests, and contemplates that to be the place of its incorporation, unless the contrary is proved. If the debtor is able to obtain recognition of a foreign main proceeding, then the bankruptcy law of its home country will govern the insolvency proceedings. ${ }^{34}$

Cross border insolvency issues are governed by applying two theories: the universality theory and the territoriality theory. The universality theory states that all assets of the insolvent company are administered by the court in the place of incorporation, and if assets of the company are located in foreign jurisdictions, then the court has the power to apply for assistance from courts in those jurisdictions. The territoriality theory instead recommends separate proceedings to be conducted for each country, and under the theory, no recognition is given to proceedings that have taken place/completed in

\footnotetext{
32 Insolvency (Cross-border) Act 2006, s 5(1) (N.Z.).

33 HANnAN, supra note 31, at 15-20.

34 John J. Chung, Chapter 15 of the Bankruptcy Code and Its Implicit Assumptions Regarding the Foreign Exchange Market, 76 Tennesse L LaW Review 74 (2008).
} 
other jurisdictions. The Model Law adopts the universality approach to cross border insolvency. ${ }^{35}$

Our focus in this section is on two aspects: (i) Recognition of Foreign Proceedings and Relief and (ii) Concurrent Proceedings.

\subsection{Extent of Adoption/Rejection/Modification of the Model Law in Chapter $Z$}

Examination of the nature of recommendations of the Insolvency Committee towards adoption of the Model Law is pivotal for the purpose of this article. Thus, we do not simply summarise the recommendations made in this article but instead examines these suggestions in light of the nature of adoption of the Model Law from a TWAIL perspective. These recommendations, broadly, are as follow:

\subsubsection{General Provisions}

The Committee recommended that the Draft Legislation be extended to corporate debtors only since Part III of the IBC has not yet been notified, and the Committee felt that extending cross border insolvency provisions of the Model Law to individuals and partnership firms would be premature. However, the Committee suggested extending the definition of a "corporate debtor" to foreign companies as well to enable access to creditors and insolvency professionals registered outside of India to avail remedies in India. ${ }^{36}$

The Committee proposed that with the introduction of cross border insolvency provisions, there arose a need to modify provisions in the Companies Act, 2013 (hereafter, also referred to as the "2013 Act") that deal with insolvency of foreign companies, such as Section 375(3)(b) that provides for winding up of companies (that may include foreign companies) for insolvency. The proposed solution for the existence of such parallel provisions was for the Ministry of Corporate Affairs to analyse the efficacy of retaining these provisions in the 2013 Act. The Committee further suggested transferring proceedings pending under the provisions of the 2013 Act for adjudication under the Code to avoid duplicating judicial efforts. ${ }^{37}$ Further, the Committee recommended amending Sections 234 and 235 of the Code to apply only "to individuals and partnership

35 Rachel Morrison, Avoiding Inherent Uncertainties in Cross-Border Insolvency: Is the UNCITRAL Model Law the Answer?, 15 Queensland University of Technology LAW REview 103 (1999).

36 Ministry of Corp. Affairs, supra note 17, $₫$ 1.2.

37 Id. ๆ 1.3. 
firms" since the proposed insolvency provisions related to corporate debtors are proposed in these recommendations. ${ }^{38}$

The Committee recommended that, initially, the Model Law would be adopted with legislative reciprocity, and thereafter, on a need basis, the reciprocity requirement would be diluted. The Committee further clarified that the reciprocity requirement was only proposed to govern the cross border insolvency provisions and not the rest of the provisions under the IBC, meaning that "foreign creditors will still be able to ... participate in ... proceedings under the Code regardless of reciprocity." ${ }^{39}$ However, the Committee refrained from explaining or even highlighting what it meant when it said that the reciprocity requirement may be diluted "based on the experience in implementation of the Model Law and development of adequate infrastructure in the Indian insolvency system." The meaning of "development of adequate infrastructure in the Indian insolvency system" is vague and difficult to assess. Does it mean a more robust implementation of the Model Law? In which case, the proposal to dilute reciprocity is incongruous.

Likewise, the Committee restricted changes to the definition of "establishment" as provided under Clause 2(c) of Draft Part Z to accommodate the meaning on "establishment" as provided in the Model Law (where limited recognition as a "foreign non-main proceeding" has been given to proceedings in countries where the debtor has an "establishment"). ${ }^{40}$ Further, in terms of having a three month look back period for determining existence of an establishment, the Committee suggested not building the same into the draft law, as adequate space has been provided to the courts in the Model Law to prevent forum shopping by defining the term economic activity with the adjective nontransitory. This was also considered in light of the fact that the three month look back period may not be earmarked "from the date of filing insolvency application in the foreign non-main proceeding." This is because it is possible that, even by such time, "no economic activity exists".41

As such, in terms of having a threshold for recognition, the Committee suggested that "the definition of non-main proceedings be limited to proceedings in countries where the corporate debtor has an "establishment"' and left out the requirement of a comI. ${ }^{42}$ The Committee suggested retaining "the definitions of "foreign court," "foreign representative," "foreign proceeding,"

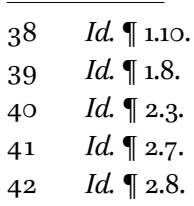


"foreign main proceeding," and "foreign non-main proceeding" as ... provided in Article 2 of the Model Law."43

Finally, the Committee recommended that, "in line with the spirit of the Model Law, the language used in Article 6 of the Model Law must be retained as it is, including usage of the term "manifestly"' in the context of interpreting public policy exceptions restrictively. ${ }^{44}$ The Committee recommended that in a situation where the Adjudicating Authority is of opinion that there is likelihood of public policy violation, a notice ought to be sent to the Central Government. The Committee further recommended that "it may be advisable to include a provision akin to [S] ection 241(2) of the 2013 Act to empower the Central Government" to take cognizance of an action that "would be manifestly contrary to public policy in India" in case notice "has not been issued by the Adjudicating Authority." ${ }^{25}$

\subsubsection{Recognition of a Foreign Proceeding and Relief}

The Committee recommended that Articles 15 and 16(1) and (2) of the Model Law "may be adopted in the present [D]raft Part Z."46 The Committee suggested that "adoption of a look-back period of three months while enforcing the сом presumption would be suitable in the Indian context." ${ }^{47}$ This recommendation is in light of "the EU Insolvency Regulation (Recast) that seeks to prevent ... forum shopping by" presuming that a corporate debtor's registered office is its сом "inapplicable in cases where the corporate debtor has relocated its registered office to" a different country within the three-month period prior to requesting for insolvency proceedings. ${ }^{48}$

The Committee for the same reasons adopted the two factors provided in the UNCITRAL Guide to Enactment to identify the COMI, namely, "(a) where the central administration of the debtor takes place; and (b) which is readily ascertainable by creditors," in order to "assist the Adjudicating Authority" to identify "the сомI when it does not coincide with the registered office." 49 The decision of recognition was suggested to be made within a timeline of 30 days by the Adjudicating Authority with a possible extension of another 30 days, in view of Article 17 of the Model Law. ${ }^{50}$ In Australia and the UK, it must be




shown on readily ascertainable evidence that the COMI is in another State. In the USA and Canada, the court requires evidence to be put before it as to the COMI, and if any of that evidence is inconsistent with the rebuttable presumption, then the court must make its own determination on the evidence presented. ${ }^{51}$

The Federal Court of Australia considers various factors while deciding the COMI, such as the place of residence of the directors, place of incorporation, place of all executive decisions, place of residence of the majority of employees, place of residence of the company's creditors, place where majority of the company's assets are located, etc. On the other hand, Canada does not have a definition or reference to an establishment nor does it state that the debtor having a СОMI as a necessary element of a non-main proceeding in their adoption of the Model Law. ${ }^{52}$

New Zealand adopted the meaning of Сом I as considered in the definition of the same in the EC Regulation, and "the court referred to the Virgos-Schmidt Report which describes a place of operations as one from which economic activities are exercised on the market (that is externally), whether the said activities are commercial, industrial or professional to give meaning to сомI." ${ }^{33}$ The English Court of Appeal, on the other hand, has relied upon the Virgos-Schmidt report to state that it depends on "whether it has in that other country a "place of operations" where non-transitory "economic activity" is carried on with human means and goods. 54 The court further stated that the determination of a COMI will require more than simply having a branch office or place where the debtor is located..$^{55}$

Further, the United States Bankruptcy Court found that an establishment ought to constitute a 'seat for local business activity' for the debtor. Terms such as "operations" and "economic activity" require demonstration of a local effect on the marketplace, more than mere incorporation, record-keeping, and simple maintenance of property therein. ${ }^{56}$ Both the UK and the USA may have put their domestic interests above the desire to achieve a degree of uniformity in the recognition of foreign insolvency and reconstruction proceedings between States. In doing so, they are evidently working against the universalist principles they espouse and upon which the Model Law is based. ${ }^{57}$

\begin{tabular}{ll}
\hline $5^{1}$ & HANNAN, supra note 31 , at 113. \\
$5^{2}$ & Id. at 49. \\
53 & Id. \\
54 & Id. at 50. \\
55 & Id. \\
$5^{6}$ & Id. at 52. \\
57 & Id. at 53.
\end{tabular}


The Model Law provides for two kinds of relief-interim relief and relief on recognition. However, the Code gives no power to the Adjudicating Authority to provide interim relief in CIRP. Hence, "the Committee recommended that power to grant interim relief may not be provided in the [D]raft Part Z." ${ }^{n 8}$ This was done particularly in light of India's experience with the Sick Industrial Companies (Special Provisions) Act, 1985 that "set a precedent for misuse of interim relief." 59

In terms of mandatory relief, the recommendation was that a moratorium in the nature of what is provided in Article 19 be implemented in the Draft Part Z, applicable in "recognition of a foreign main proceeding," along with "the exceptions and limitations applicable to the moratorium in Section 14 of the Code." 60 This is interesting from a TWAIL perspective, as Article 20 of the Model Law calls for "an automatic moratorium ... on recognition of foreign main proceedings" which aligns with the overall approach, as recognized in this Report, of an overarching significance given to "domestic insolvency proceedings of the enacting country over foreign proceedings." ${ }^{\prime 1}$

The Committee suggested that "a provision similar to Article 2O(3) of the Model Law may be inserted in the [D]raft Part Z to ensure" the subsistence of "the right to commence individual actions or proceedings against the corporate debtor to the extent necessary to preserve claims against the corporate debtor," in the face of automatic moratorium. ${ }^{62}$ Likewise, the Committee suggested complete adoption of Article 20(4) of the Model Law which provides that the moratorium as given in Article 2O(1) does not impede the right of the creditor to initiate domestic insolvency proceedings. ${ }^{63}$

However, when it comes to discretionary relief and the scope of the adjudicating authority to assess the same, the Committee makes a cautionary case, and suggests that the same ought to be exercised in light of the moratorium provisions under Section 14 of the Code. ${ }^{64}$ Similarly, the Committee recommended not adopting Article 21(d) that provides "examination of witnesses and collecting information and evidence regarding the debtor," since such power is already available to the insolvency professional under the Sections 18, 29, and 23 of the Code. ${ }^{65}$

\begin{tabular}{|c|c|}
\hline $5^{8}$ & Ministry of Corp. AfFairs, supra note $17, \boldsymbol{~} \mathbf{1 3 . 4}$. \\
\hline 59 & Id. $\uparrow 13.4$ \\
\hline 60 & Id. $\uparrow 14.3$. \\
\hline 61 & Id. $\rrbracket$ 14.2. \\
\hline 62 & Id. $\rrbracket 14.6$. \\
\hline 63 & Id. $\uparrow 14.7$. \\
\hline 64 & Id. $ๆ 14.9$ \\
\hline 65 & Id. ๆ 14.10. \\
\hline
\end{tabular}


While discarding the provisions for discretionary relief (Article 21) and interim relief (Article 19), the Committee sounded a note of caution for them to be exercised sparingly, and recommended full implementation of "Article 22 of the Model Law [that] provides courts with the flexibility to impose conditions on the reliefs" provided under Articles 19 and 21 and/or their modification and termination. ${ }^{66}$

The Model Law proposes prioritizing relief given in terms of insolvency proceedings against the debtor in foreign main proceedings over foreign nonmain proceedings. This hierarchy of relief as provided to foreign main and non-main proceedings, as a general principle of the Model Law, has been accepted by the Committee without any deviation. ${ }^{67}$

Article x of the Model Law on Recognition and Enforcement of InsolvencyRelated Judgments ("MLREIJ") provides that the relief available under the corresponding legislation in the State enacting Article 21 of the Model Law includes recognition and enforcement of an insolvency judgment includes recognizing and enforcement of such judgment. ${ }^{68}$ The Committee agreed with this proposition and suggested including enforcement of judgments as a relief as well, "if deemed fit by the Adjudicating Authority."69 However, the Committee reserved discussion on the legislative changes pertaining to this for a later stage. ${ }^{70}$

Article 23 of the Model Law describes actions that are detrimental to creditors. Article 23(2) for instance states that when the foreign proceeding is a foreign non-main proceeding, the court ought to ascertain that the action relates to assets that, under the law of that particular state, should be administered in the foreign non-main proceeding. ${ }^{71}$ The Committee recognizes this as another remedy on recognition of foreign proceedings, in addition to Articles 20 and 21 of the Model Law. However, the UnCitral Guide to Enactment left it open to domestic legislation to deal with, resolve, and implement such remedy "to foreign representatives to initiate avoidance actions on recognition of foreign proceedings. ${ }^{.72}$ As such, the Committee concluded that Article 23 of the Model Law may be adopted as recommended in the Model Law, subject to the access available to the foreign representative according to

\begin{tabular}{ll}
\hline 66 & Id. ๆ 14.12. \\
67 & Id. ๆ 14.14. \\
68 & Id. | 14.15. \\
69 & Id. \\
70 & Id. \\
71 & Id. ๆ 15.4. \\
72 & Id. ๆ 15.3.
\end{tabular}


paragraph 15.4 of the Report (that invokes adopting a conservative approach in providing access to foreign representatives till "the development of infrastructure regarding cross-border insolvency in India" and development of subordinate legislation), with the date of commencement of insolvency proceedings for obtaining the relief against avoidance actions being the date of opening of the foreign proceedings. ${ }^{73}$

In the UK, a foreign representative has the power to issue proceedings under various Sections of the UK Insolvency Act, however, leave of the court must be granted to the foreign representative by an appropriate court before issuing any proceedings where there is a concurrent British insolvency proceeding ongoing pertaining to the same debtor, as provided under Article 23(6) of the Model Law. ${ }^{74}$ Likewise, in the USA, the foreign representative, once recognized, is granted power to bring proceedings in a separate proceeding issued under another chapter of the Bankruptcy Code which is pending. ${ }^{75}$

"No amendments of substance have been made to [Article 19] in Australia, New Zealand, or the UK. However, New Zealand imposes an obligation upon the foreign representative to notify the debtor in a prescribed form as soon as practical after an interim relief has been granted." 76 There is also no corresponding provision in the Canadian legislation; however, the court can apply legal and equitable rules regarding recognition of foreign insolvency proceedings. The US also provides that such interim relief cannot be granted if it might enjoin a police, regulatory or government unit. Further, the grant of relief is subject to the "standards procedures and limitations applicable to injunctions." ${ }^{77}$ However, the US Bankruptcy Court has held that the standards for obtaining a preliminary injunction under Section 1519 (e) are not the same as those for obtaining an injunction in adversary proceedings and that the court has the power to grant stays under Section 362 of the Bankruptcy Code. ${ }^{78}$

An interesting application of Articles 21(3) and 22(2) of the Model Law was when the English High Court granted conditional interim relief staying the enforcement of a lien in England pending the determination of an appeal over the quantity of the creditor's provable debt in Korea, the place of the main proceeding, upon an undertaking being given that the fact that the creditor who appeared in the Korean proceeding would not create an estoppel in

\begin{tabular}{ll}
\hline 73 & Id. $\mathbb{1} 15 \cdot 5 \cdot$ \\
74 & HANNAN, supra note 31 , at 143. \\
75 & Id. at 144. \\
76 & Id. at 125. \\
77 & $I d$. at 124. \\
78 & $I d$. at 125.
\end{tabular}


England to the creditor enforcing its lien, as decided in Norden $v$. Samsun Logix Corporation [2009] BPIR $1367 .{ }^{79}$

\subsubsection{Australia}

In Australia, the Full Federal Court held that where there is, "an application for assistance from a prescribed country under the statutory provisions in respect of personal bankruptcy, recognition must be granted." 80 The court does not have discretion in this regard. Thus, recognition is given to a foreign representative who seeks to collect the debtor's property and then distributes it according to law. The Federal Court had also indicated that an application for recognition to be made under the Model Law was not necessary, instead an application for assistance can be made under the provisions of the Bankruptcy Act 1966 (Cth) (Bankruptcy Act). ${ }^{81}$ Hence, this suggests that the domestic law that allows the court to extend assistance to other foreign courts in nominated countries exercising bankruptcy jurisdiction takes precedence over similar provisions in the Model Law. The Cross-Border Insolvency Act 2008 (Cth) Sections 29-30 provide that to the extent the provisions of the existing law are inconsistent with the Model Law, the provisions of the Model Law shall prevail.

The common law principles of comity apply in Australia, according to which foreign representatives can be recognized. When a foreign court requests for recognition of a foreign representative to whom the Model Law does not apply or who cannot avail him/herself of the statutory rights of recognition, the principle of comity will allow a court to do the same. If recognition is granted under either Statute or the principles of comity, the court has a discretion to decide what assistance it will give to that court or representative. ${ }^{82}$

\subsubsection{Canada}

In Canada, Section 48(4) of the CCAA states that seeking an order for recognition under the provisions of its enactment of the Model Law does not prevent proceedings from being commenced under the BIA or the Winding-up and Restructuring Act. Likewise, Section 284 of the BIA provides that nothing in that Act prevents a court from applying the legal and equitable rules governing recognition of foreign insolvency orders on applications of any foreign representative or other interested party. ${ }^{83}$ However, in Canada, there is no provision

\begin{tabular}{ll}
\hline 79 & Id. at 134. \\
8 o & Id. at 24. \\
81 & Id. \\
82 & Id. \\
83 & Id. at 29.
\end{tabular}


for the adequate protection of creditors and interested persons within the meaning of Article 22 of the Model Law. Section 187(5) of the Canadian BIA allows a court to review, rescind or vary any order made under its bankruptcy jurisdiction. ${ }^{84}$

\subsubsection{New Zealand}

"Section 8 of the Insolvency (Cross-border) Act 2006 of New Zealand provides that if a court of another country in an insolvency proceeding makes an order requesting the aid of the High Court in respect of a person to whom Article 1 of the Model Law applies, the High Court may if it thinks fit, act in aid of and be auxiliary to that court in insolvency proceedings." 85 The Companies Act 1993 similarly allows an application to be made to the High Court for the liquidation of a foreign company; such applications are not contingent upon the debtor having assets in New Zealand. ${ }^{86}$

\subsubsection{United Kingdom}

The default position for English Courts is that the principle liquidation would be deemed to be the place of incorporation of the company. It is often argued, for instance in Schmitt $v$ Deichmann [2012] 2 All ER 1217, 1232-3 [6265], that under the English common law, the courts "have the power to assist foreign courts to help a foreign representative, pursuant to the principles of comity[, by acts] pursuant to domestic English law." 87

The Insolvency Act 1986 (UK Insolvency Act) provides that a court having insolvency jurisdiction shall assist the court of another relevant jurisdiction as prescribed. This power has been said to be limited to requests made by foreign court where there is an insolvency proceeding on foot in that State. Common law allows the court to apply either the UK domestic law or the law of the relevant State and apply the rules of private international law. Moreover, nothing in such provisions restricts UK courts' powers to request assistance from a foreign court which is derived from the common law. Hence, recognition can occur as a result of an application under the Model Law or by way of a letter of request from a foreign court. ${ }^{88}$

\begin{tabular}{ll}
\hline 84 & Id. at 141. \\
85 & Id. \\
86 & Id. at 29. \\
87 & Id. at 31. \\
88 & Id. at $3{ }^{2-}-33$.
\end{tabular}




\subsubsection{USA}

The common law position of comity has been recognized by the courts in the USA as early as 1883 and continues to apply. Chapter 15 of the Bankruptcy Code recognizes that the granting of recognition and any assistance given following recognition of a foreign proceeding must be consistent with the principles of comity. Where the party seeking recognition of a foreign judgment is not a foreign representative, then the relevant State law principles for recognition apply. However, the issue that persists is whether by using the word 'comity' in Chapter 15 , it is a core matter under the Bankruptcy Code and whether the US Bankruptcy Court can continue to apply the common law principle of comity since the introduction of the Model Law provisions in Chapter $15 .{ }^{89}$ In the USA, Article 22 permits a court to grant relief under Articles 19 or 21 "only if the interests of creditors and other interested parties, including the debtor are sufficiently protected" within the meaning of Section 111 USC $§ 1522(\mathrm{a})(2012) .{ }^{90}$

\subsection{Concurrent Proceedings}

The Committee examined Articles 28 and 29 and the lowering of the threshold of commencement of insolvency proceedings by enabling initiation of proceedings after recognition of a foreign main proceeding, provided "the debtor has assets in the enacting country." ${ }^{11}$ The Committee read Article 28 with Article 29 to analyse that the subsistence of a foreign proceeding will not impede commencement of a local insolvency proceeding, in other words, both the foreign and domestic insolvency proceedings can take place concurrently, subject to the possible modifications of relief as provided in Article 29. The Committee thus recommended that Articles 28 and 29 of the Model Law may be included in the Draft Part Z.92

Similarly, the Committee suggested adoption of Article 30 of the Model Law that provides for "modification of relief given under Articles 19 or 21 for" the purpose of "coordinating multiple foreign proceedings." 93 However, the Committee excluded references to interim relief as the same has not been recommended by the Committee earlier in their Report. ${ }^{94}$

Article 30 deliberates how the pursuit of concurrent insolvency proceedings may culminate in receiving claims in more than one jurisdiction, hence this article seeks to address such double award of claims due to concurrent

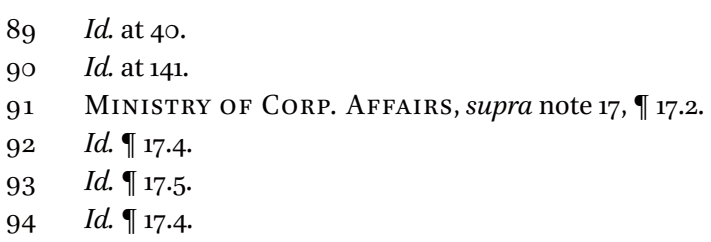


proceedings through effective coordination among jurisdictions. This is provided for, with the just exception that the creditor will not be denied a higher benefit in one jurisdiction if she has received part of a claim of a "lower value in a prior insolvency proceeding" against the same debtor. ${ }^{95}$ The Committee recommended the adoption of Article 30 in the Draft Part Z with two modifications: "(i) in case of a domestic insolvency resolution process in India, the payment to creditors would be according to the resolution plan and (ii) in case of liquidation under the code, the bar for comparison ought to be creditors of the same class and ranking." 96

Article 31 of the Model Law provides a presumption of insolvency "on recognition of a foreign main proceeding ... for the purposes of ... initiation of a domestic insolvency proceeding." ${ }^{97}$ However, a test of insolvency already exists in India under Section 4 of the IBC whereby, the CIRP can be initiated on default of INR 1 lakh. ${ }^{98}$ As such, the Committee suggested that in place of a test of insolvency, "recognition of a foreign main proceeding may be presumed" as "proof of default by the corporate debtor" to initiate CIRP. ${ }^{99}$

And finally, the Committee recommended adding a proviso that for a default to be deemed within the meaning of Part II of the IBC "based on recognition of a foreign main proceeding, the foreign main proceeding recognized in India" ought to have been "initiated based on an inability to pay debts or pursuant to a state of insolvency."100 This was suggested in light of how certain jurisdictions recognise foreign proceedings though they do not strictly adhere to the definition of a "foreign proceeding."101

The UK interpretation of Article 28 does not restrict representatives to deal only with the local assets within Great Britain once a foreign main proceeding is recognized. In the USA, however, the subsequently appointed domestic representative is restricted to deal only with the assets which are within the territorial jurisdiction of the USA and not subject to the control of the foreign proceedings. Likewise, in the UK, when domestic proceedings are issued after recognition of a foreign proceeding, the court ought to review any leave granted to the foreign representative under Article 23 to issue proceedings for recovery of antecedent transactions. ${ }^{102}$

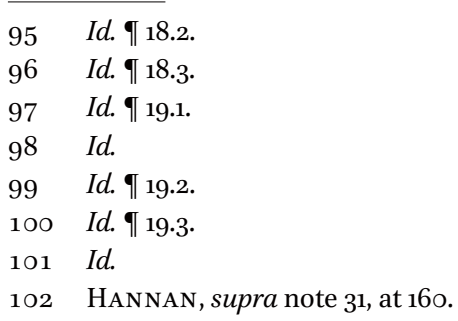


In UK, USA, and Australia, where two foreign non-main proceedings are recognized, the court is required to modify its relief in the first proceeding to facilitate coordination between the two proceedings. The Canadian legislation, however, does not deal with this possibility.103

\section{Lessons - In Lieu of a Conclusion}

The bulk of our article, sections two and three, consists of demonstrating the nature of State Practices emanating from India, a Third World nation. The emphasis on the Third World status of India has not been emphasized in our earlier sections. This is deliberate. It serves the function of demonstrating the actions that the Indian State has taken. This section is an attempt to analyse and interpret the aforementioned actions in the context of the TWAIL.

There is considerable literature, from earlier in the TWAIL movement, that define what TWAIL is. ${ }^{104}$ It was envisioned as a movement that is political in nature but its politics was informed by a small set of coordinates ${ }^{105}$ that allow it to navigate the illegitimacies of international law. ${ }^{106}$ These coordinates are; that historical context matters, that both the Global North and its institutions move, that the South moves as well, and that attempts to struggle against the stranglehold of multilateral institutions are multiple. ${ }^{107}$ TWAIL is a response to the methodological syncretism that dominated Hans Kelsen's thinking. In this, the law and the authors of it are not to be bothered by the context, social, political, economic, or otherwise, in which a set of rules operate but rather emphasize the doctrinal integrity of the rules themselves. ${ }^{108}$

Our second section demonstrates two major conclusions. The first of these two conclusions is that a historical inquiry into India's State Practices demonstrates that it has acted in a manner that, over time, has enabled the adoption of the Model Law (see Section 2. C. I). By highlighting the role that a sound cross border insolvency law has in the context of a growing modern economy, the Eradi Committee opened the doors for the adoption of Model

\footnotetext{
103 Id. at 163.

104 Makau W. Mutua, What Is TWAIL?, 94 Proceedings of the American Society of International Law ANnUal MeEting 31 (2000).

105 Luis Eslava, TWAIL Coordinates, Critical Legal Thinking (Apr. 2, 2019), http:// criticallegalthinking.com/2019/o4/o2/twail-coordinates/ (last visited Oct. 9, 2019).

106 Mutua, supra note 104, at 31.

107 Id.

108 Research Handbook on Global Justice and International Economic Law 251 (John Linarelli ed., 2013).
} 
Law in India. The Macquarie Bank Limited v. Shilpi Cable Technologies Ltd. judgment enabled the foreign operational creditors to pursue insolvency proceedings in India. And the Report of the Insolvency Law Committee, 2018 finally recommended that the Model Law be adopted. Our second conclusion is that India's State Practices are operating within the context of a discourse emanating from the multilateral institutions. ${ }^{109}$ This conclusion is consistent with Antony Anghie's analysis. ${ }^{110}$ Third World States such as India operate within the "rules of the game"111 set by these multilateral institutions ${ }^{112}$ that has far exempted the scope their Articles of Agreement envisioned for them. ${ }^{113}$

Through mechanisms like the Ease of Doing Business Rankings that promise increases in foreign investment, a country like India is incentivized to reform its local laws in a manner conducive to the adoption of Model Law and its ilk. India's surge in the most recent rankings can directly be attributed to this induced reform. ${ }^{114}$ The problem with this is that it remains consistent with what Anghie demonstrates is the positivist core of international law that is inherently to blame for the violence committed against the inhabitants of the Third World due to the colonial origins of international law. ${ }^{115}$ This legitimation of violence against the peoples of the Third World brutally underscores the idea that sovereignty is the preserve of European nations and not the Third World. ${ }^{116}$

As such, an adherence to the International Monetary Fund and its directives and the other softer forms of global governance makes the Third World state impotent ${ }^{117}$ and, therefore, constrains its ability to execute its basic responsibilities towards its citizens' interests.

109 Antony Anghie, Imperialism, Sovereignty And the Making of InterNATIONAL LAW 251 (2004).

110 Antony Anghie, Time Present and Time Past: Globalization, International Financial Institutions, and the Third World, 32 New York University Journal of InTERnATional LAW \& Politics 243 (2000).

111 Douglass C. North, Institutions, Ideology, and Economic Performance, 11 Cato Journal 477 (1992).

112 Anghie, supra note 110, at 243.

113 Id. at 272.

114 ET Bureau, Ease of Doing Business: India among 20 Most Improved Countries, THE EcoNOMic Times (Sept. 29, 2019), https:/economictimes.indiatimes.com/news/economy/ indicators/ease-of-doing-business-india-among-2o-most-improved-countries/article show/71357483.cms.

115 Antony Anghie, Finding the Peripheries: Sovereignty and Colonialism in Nineteenth-Century International Law, 4O HARVARD InTERnATIONAL LAW JOURNAL 1, 7 (1999).

116 Id.

117 Boris Kagarlitsky, The Twilight of Globalization: Property, State and CAPitAlism 14 (2000). 
In our third section, through an exhaustive comparative exercise, we arrive at one crucial conclusion. First World common law countries, when compared with a Third World common law country like India, display differences in a manner in which they have chosen to adopt the Model Law based on domestic priorities. As India has not yet adopted the Model Law, there are important lessons for India to keep in mind when the legislature takes over the process of formally adopting the Model Law. Among the most significant domestic priorities to keep in mind is the fact that the largest source of credit, that is financial capital, are the Public Sector Banks ${ }^{118}$ which are in the midst of a crisis of bad loans. ${ }^{119}$

Thus, India's adoption of the Model Law should reflect the realities of domestic credit markets lest we end up throwing the baby out with the bathwater when adopting the Model Law. More fundamentally, this would serve as an effective response to one of international laws' inherent tendencies - a regime bias against the Third World nations ${ }^{120}$ and thus confront the existing state of global power relations. ${ }^{121}$ This confrontation matters.

Too often, international law operates in a manner that works against an idea of the common good. ${ }^{122}$ That is, international law promotes too narrow an understanding of best interests while simultaneously working to undermine alternative conceptions of the idea of the good life. ${ }^{123}$ Examining international law at one of its peripheries in the Third World enables us to carry stories from these peripheries, ${ }^{124}$ identify its discontents, ${ }^{125}$ and to confront its hegemonic

118 See India Commercial Guide, International Trade Administration, https://www .export.gov/article?id=India-Banking-Systems (last visited Oct. 9, 2019).

119 See Ministry of Finance, Bank NPA, Press Information Bureau, Government OF INDIA (June 24, 2019), https://pib.gov.in/newsite/PrintRelease.aspx?relid=190704 (last visited Oct. 9, 2019).

120 Usha Natarajan et al., Introduction: TWAIL - On Praxis and the Intellectual, 37 THIRD WORLD QUARTERLY 1946, 1954 (2016).

121 Gus Van Harten, TWAIL and the Dabhol Arbitration, 3 Trade, LAW And Development 131 (2011).

122 Michael Fakhri, Questioning TWAIL's Agenda, 14 Oregon Review of InTERnATIONAL LAW 1, 4 (2012).

123 B.S. Chimni, The Past, Present and Future of International Law: A Critical Third World Approach, 8 Melbourne Journal of International Law 499 (2007).

124 Michael Fakhri, Law as the Interplay of Ideas, Institutions, and Interests: Using Polyani (and Foucault) to Ask TWAIL Questions, 10 International Community LaW Review 464 (2008).

125 Balakrishnan Rajagopal, International Law and Its Discontents: Rethinking the Global South, 106 Proceedings of the Annual Meeting (American Society of InterNATIONAL LAW) 176 (2012). 
discourses. Moreover, it enables us to reframe the discourse of the outcomes produced by international law in the context of the Third World and, therefore, opens up conversations on global responsibility that are crucial to a fuller realization of justice. ${ }^{126}$

126 Kwadwo Appiagyei-Atua, Ethical Dimensions of Third-World Approaches to International Law (TWAIL): A Critical Review, 8 African Journal of Legal Studies 209, 235 (2015). 